\title{
Motivation Of Bali Cattle Farmers Tinanggea and Palangga Subdistrict South Konawe Regency
}

\author{
La Ode Arsad Sani ${ }^{1}$, Harapin Hafid ${ }^{1}$, La Ode Muh Munadi*1, \\ Deki Zulkarnain ${ }^{1}$, and Sitti Rahma Ratu Pujian ${ }^{1}$ \\ ${ }^{1}$ Faculty of Animal Husbandry, Halu Oleo University, Kampus Hijau Bumi \\ Tridharma, Anduonohu, Kendari, Southeast Sulawesi. \\ ${ }^{*}$ Corresponding Author: \\ Email:1mmunadi@yahoo.com

\begin{abstract}
.
Tinanggea and Palangga subdistricts of South Konawe Regency have many cattle farmers and relatively more populations than other livestock. The research aims to find out the motivation of farmers in raising bali cattle in Tinanggea and Palangga subdistricts in June - July 2020. Sub-districts and villages were determined by purposive sampling based on the largest number of livestock, while respondents selected as many as 60 farmers in simple random sampling. Furthermore, the data obtained is analyzed using The Likert scale and explained derpively. The results showed a strong reason farmers keep Balinese cattle because of economic motivation (68.8\%), entertainment motivation (56\%), environmental motivation (36\%), and (4) social status motivation (22\%).
\end{abstract}

Keywords: Motivation, Farmer, Economy, Environment, Entertainment, Social Status.

\section{INTRODUCTION}

The potential of cattle development in this area is quite large because it is supported by the topography of vacant land areas that are still available quite widely and utilize the waste of plantations as a source of animal feed and grazing sites $[1,2,3$, 4]. The success of livestock development, especially in Tinanggea and Palangga subdistricts is not only determined by the availability of facilities or facilities and infrastructure, capital and other tools, but also depends on how much motivation farmers have in managing cattle businesses. Motivation is one of the determining aspects of the success of livestock business as an economic activity in increasing income and meeting the needs of families $[5,6]$.

This type of business as a source of livelihood of the people of Tinanggea and Palangga subdistricts in addition to raising cattle, also has several other livestock businesses such as goats and chickens as well as some types of farming such as plantations and rice fields. However, cattle relatively have a relatively higher population than other types of cattle, so it is necessary to conduct a more in-depth study of what motivations make the reason people prefer to raise cattle than other types of cattle. 
South Konawe Regency in 2018 has a cattle population of 60.915 heads and about $16.26 \%$ of the livestock population is in the area of Tinanggea and Palangga subdistricts, while the remaining $84.85 \%$ is spread over 23 other subdistricts in the South Konawe Regency. The research aims to analyze the motivation of farmers in raising Balinese cattle in Tinangga and Palangga subdistricts. It is expected that the research provides benefits to identify the potential of being a reliable and motivated farmer to increase the scale of his livestock business, increase insight and knowledge to several factors that influence the motivation of farmers in raising cattle and as an additional information material in formulating the policy of livestock business development.

\section{METHODS}

Research has been conducted in June-July 2020 in Tinanggea and Palangga subdistricts of South Konawe Regency. The research covers two stages, the first is the preparatory stage and the second is the implementation stage. The preparatory stage is to conduct a survey of the research site to obtain an overview of the potential of the farm. Implementation stage, namely conducting interviews to collect primary data and secondary data related to research.

Location determination is done intentionally (purposive sampling) with the consideration that the location has the largest population of cows. The selected locations are Palangga Subdistrict including Aosole and Wawouru Villages as well as Tinanggea Subdistrict asingi Village and Ngapaha Village. Respondents will be taken as many as 15 people from each village by simple random sampling. Thus, the total number of respondents taken was 60 people ( 4 villages $\times 15$ people $=60$ people).

Data and information on the characteristics of respondents and the model of management of cattle business as the first research objectives will be collected and tabulated and then explained descriptively. The motivation of raising cows will be measured using the Likert scale, which is scoring by forming five categories of answers expressed by integers 1, 2, 3, 4 and 5. Scoring technique, where the highest score is 5 given for the most expected answer and the lowest score is 1 for the least expected answer. The answer score will be calculated using the equation:

$$
\text { Score Score Obtained }(\%)=\frac{\text { Answer score }}{\text { Highest score }} \times 100
$$

Furthermore, analyzing the motivation level of breeding cows, a category is created using the class interval formula as follows:

$$
\begin{aligned}
\text { Class interval }(\%) & =\frac{\text { Highest score-Lowest score count }}{\text { Number of ciasses }} \\
\text { Class interval }(\%) & =\frac{\frac{300}{300} \times 100-\frac{60}{300} \times 100}{5} \\
\text { Class interval }(\%) & =\frac{100 \%-20 \%}{5}=16 \% \\
& \text { http://ijstm.inarah.co.id }
\end{aligned}
$$


Based on the class interval formula, the motivation level of cattle breeding by farmers in Tinanggea and Palangga subdistricts can be arranged in tier categories as in Table 1.

Table 1. Level of breeding motivation category

\begin{tabular}{cllll}
\hline \multirow{2}{*}{$\begin{array}{c}\text { Percentage of score } \\
\text { achievement }(\%)\end{array}$} & \multicolumn{4}{c}{ Level of breeding motivation category } \\
\cline { 2 - 5 } & motives & Social status & $\begin{array}{c}\text { Environmental } \\
\text { motives }\end{array}$ & $\begin{array}{c}\text { Entertainment } \\
\text { motives }\end{array}$ \\
\hline $20-36$ & Very low & Very low & Very low & Very low \\
$>36-52$ & Low & Low & Low & Low \\
$>52-68$ & Are & Are & Are & Are \\
$>68-84$ & High & High & High & High \\
$>84-100$ & Very high & Very high & Very high & Very high \\
\hline
\end{tabular}

\section{RESULT AND DISCUSSION}

\section{Motivation to Raise Balinese Cows}

Motivation is a force that encourages a person to do something to achieve a goal. The motivations analyzed in this study include economic motivation, environmental motivation, entertainment motivation and social status motivation. The division is intended to make it easier to group different types of motivations. Motivation score can be seen in Table 2 .

Table 2. Motivation Category Score Score

\begin{tabular}{lcc}
\hline Motivation & Score (\%) & Category \\
\hline Economic Motivation & 68.8 & High \\
Environmental Motivation & 36 & Low \\
Entertainment Motivation & 56 & Are \\
Social Status Motivation & 22 & Very Low \\
\hline
\end{tabular}

Based on Table 2 that cattle farmers in Tinanggea and Palangga subdistricts have high economic motivation compared to other motivations such as the environment, entertainment and social status. Economic motivation falls into the high category with a percentage score of $68.8 \%$ but environmental motivation falls into the low category with a percentage score of $36 \%$, entertainment motivation falls into the moderate category with a percentage of $56 \%$ and For social status motivation falls into the very low category with a percentage of $22 \%$. This proves that the most powerful motivation to encourage farmers to raise cattle in Tinanggea and Palangga subdistricts is economic motivation. The strong reason farmers are eager to increase income, livestock owned can be a savings and can be additional income.

\section{Economic Motivation}

Percentage of farmers who express breeding attitudes as economic motives are presented in Fig. 1. 


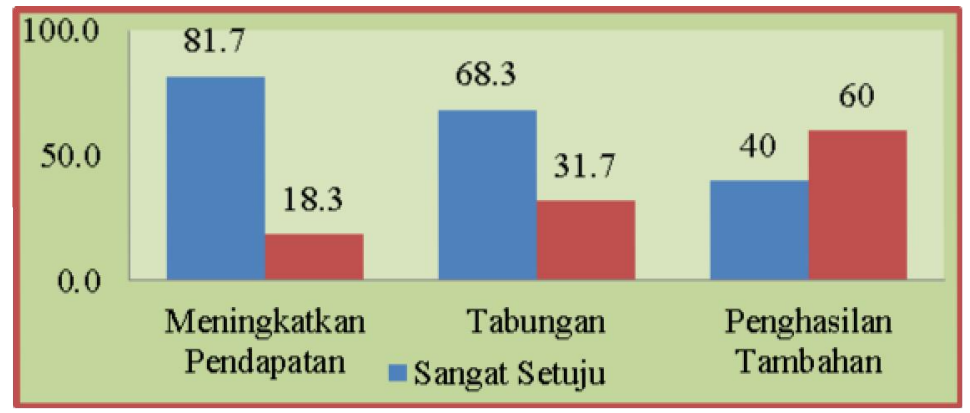

Fig 1. Percentage of Economic Motives of Raising Cows can Increase Income, as Savings and As Additional Income.

Fig 1. Shows that the percentage of farmers in Tinanggea and Palangga subdistricts who expressed a strongly agreed attitude if raising cows can increase income, as savings, and as additional income as much as $81.7 \%, 68.3$, and $40 \%$ respectively. Farmers agreed to raise cattle to increase income, as savings and as additional income by $18.3 \%, 31.7 \%$ and voted to agree by $60 \%$

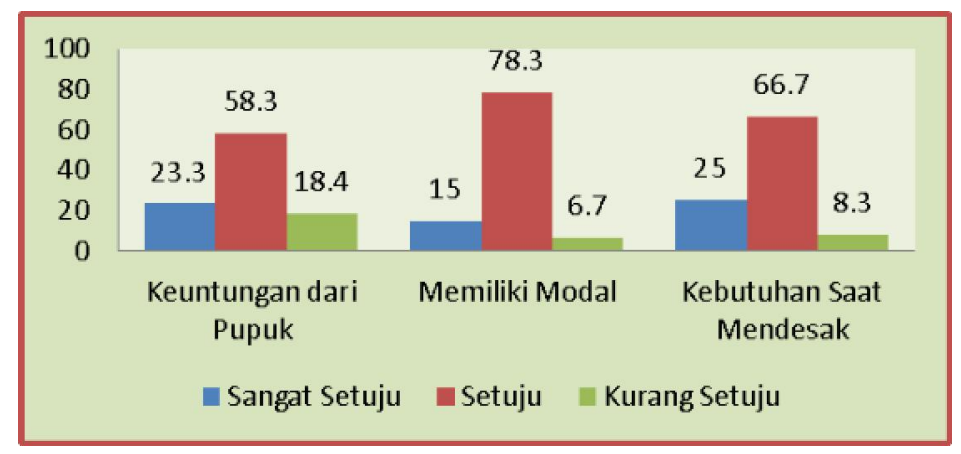

Fig. 2. Percentage of Economic Motives of Raising Cattle can Benefit from Fertilizer, Because It Has Capital, and Meets Urgent Needs

Fig 2. Showing that the percentage of farmers in Tinanggea and Palangga subdistricts expressed agreed attitude on the statement about farmers can benefit from fertilizer as much as $58.3 \%$, a strongly agreed attitude of $23.3 \%$ and a disapproval attitude of $18.4 \%$. For cattle breeding statements because farmers have capital has a high percentage of agreed attitude as much as $78.3 \%$ while for the attitude of strongly agree as much as $15 \%$ and less agree $6.7 \%$. For cattle breeding statements can meet the needs when urgent have a percentage of agreed attitude as much as $66.7 \%$, strongly agree $25 \%$, and less agree as much as $8.3 \%$.

Based on the results of this study farmers in Tinanggea and Palangga subdistricts have a high percentage of economic motivation. Farmers argue that by raising cattle farmers can increase the family income, saved as savings and made as additional income. The most powerful motivation to encourage farmers in Buru Regency is economic motivation $[7,8]$. This proves that the strong reason farmers are the desire to increase income and the desire to have and increase savings, namely the urge to have 
savings and increase the savings owned, Livestock owned can be a family savings that can be sold at any time $[9,10]$.

\section{Environmental Motivation}

The results of research in environmental motivation showed that overall farmers have a low category of environmental motivation by choosing a very agreeable attitude that is lacking and agreed and less agreeable to the statement about raising cows because of the neighboring environment and the environment where the average cow is kept. This can be seen in Fig 3.

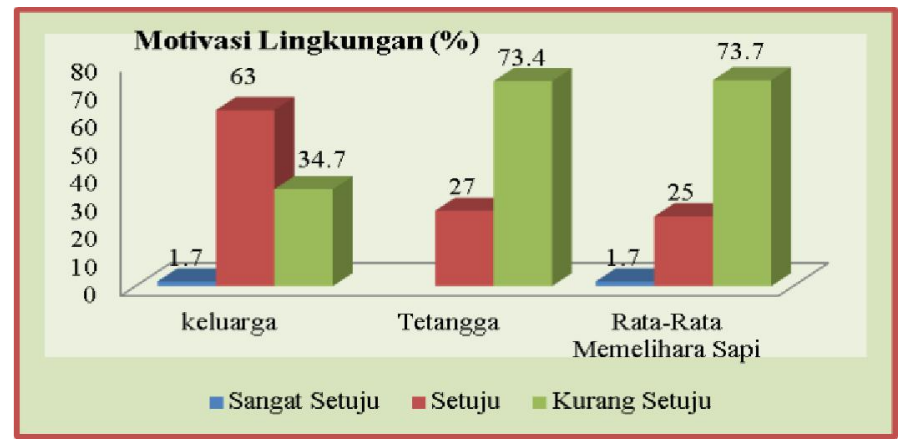

Fig. 3. Percentage of Environmental Motives of Raising Cows due to The Influence of Family Environment, Neighbors and Average Cow Rearing

Fig 3. Shows that the percentage of farmers in Tinanggea and Palangga subdistricts who expressed a strongly agreed attitude if raising cows due to the family environment and the environment where the average cow is kept by $1.7 \%$. Farmers expressed agreed to raise cows because the family environment, neighbors and the average cow rearing as much as $63 \%, 27 \%$ and $25 \%$ respectively. As for farmers who choose the attitude of less agreeing to the statement of raising cows due to the family environment, neighbors and the average cow rearing as much as $34.7 \%, 73.4 \%$ and $74 \%$ respectively.

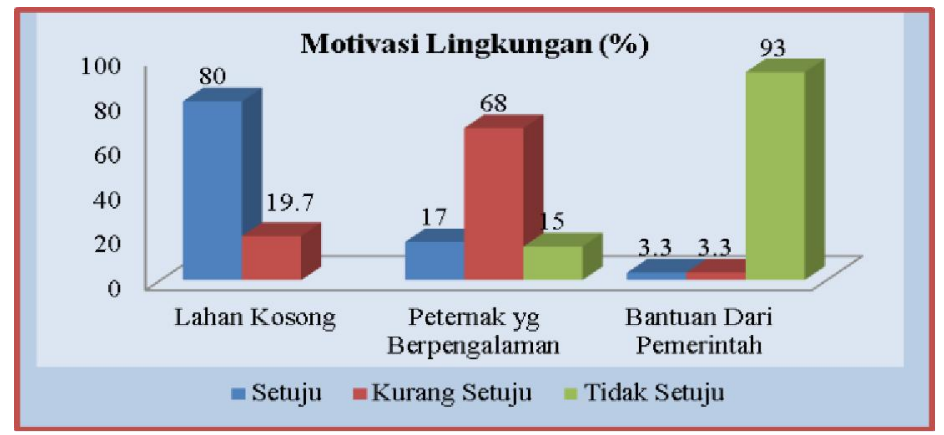

Fig. 4. Percentage of Environmental Motives of Raising Cows due to The Existence of Vacant Land, Experienced Farmers and Assistance from the Government 
Fig 4. It shows that the highest percentage of farmers in Tinanggea and Palangga subdistricts voted strongly against the statement about cattle breeding farmers because they received $93 \%$ of local government assistance, 3.3\% agreed and 3.3\% disagreed. For cattle breeding statements due to the large number of experienced farmers have the highest percentage for disapproval as much as $68 \%$, choose to agree as much as $17 \%$ and strongly disagree as much as $15 \%$. As for the statement of owning vacant land the highest percentage of votes agreed as much as $80 \%$ and for the percentage of less agreed as much as $19.7 \%$.

Based on the results of this study, farmers in Tinanggea and Palangga subdistricts showed that their desire to raise cows is due to seeing the family environment and the environment around the average breeding lot and the existence of vacant land so as to give rise to their motivation to raise cows.

\section{Entertainment Motivation}

The results of research in the entertainment motivation category is showing that farmers have high environmental motivation by choosing to agree, disagree, disagree and strongly agree on statements about raising cows because of the absence of other activities, can be a means of entertainment, as a filler of free time, can be used as an additional activity and raise cows because of the willingness to raise. This can be seen in Fig 5.

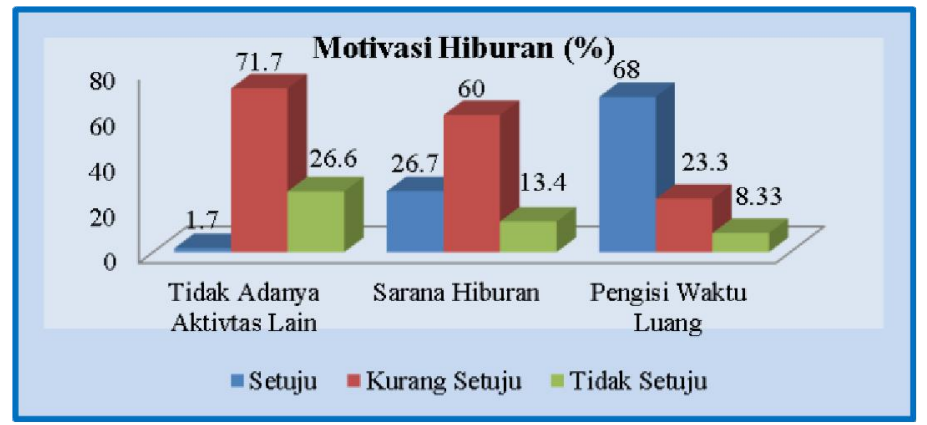

Fig. 5. Percentage of Entertainment Motives Raised Cattle due to The Absence of Other Activities, As a Means of Entertainment and As a Filler Free Time

Fig 5. Shows that the highest percentage of farmers in Tinanggea and Palangga subdistricts chose a disapproval of the statement about raising cows due to the absence of other activities as much as $71.7 \%$ and as a means of entertainment chose a disapproval attitude of $60 \%$ while for free time fillers the highest percentage of farmers chose agreed attitude of $68 \%$. For the percentage of agreed, strongly disagree is relatively low that is for the statement of absence of other activities percentage of the percentage of the vote agreed as much as $1.7 \%$ and strongly disagreed as much as $26.6 \%$. For the statement as a means of entertainment percentage farmers choose to agree as much as $5 \%$, and strongly disagree as much as $13.4 \%$. As for the statement as 
a free time filler percentage of farmers choose to agree as much as $5 \%$ and disagree as much as $23 \%$.

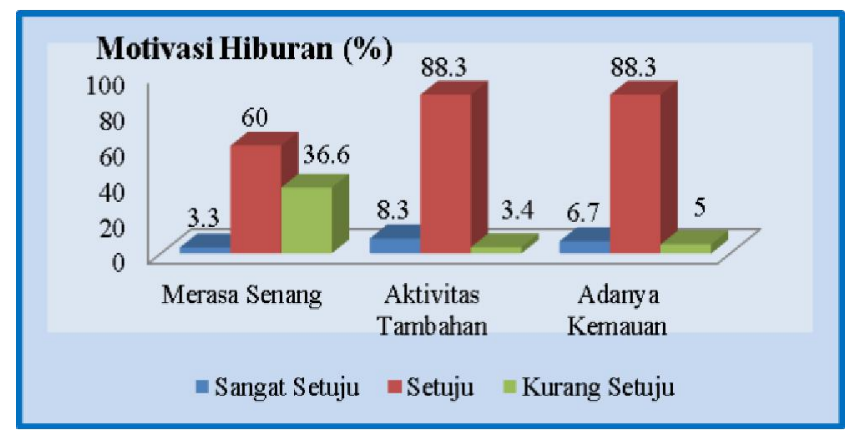

Fig. 6. Percentage of Entertainment Motives of Raising Cows by Raising Cows can Provide Fun, As Additional Activities and The Existence of Willpower.

Fig 6. Showing that the highest percentage of farmers in Tinanggea and Palangga subdistricts chose to agree on the statement about raising cows made me feel happy as much as $60 \%$, as an additional activity as much as $88.3 \%$, and because of the will as much as $88.3 \%$. As for the percentage of strongly agree, disagree and disagree is relatively low that for the statement of raising cows can make me feel happy very agree as much as $3.3 \%$, less agree as much as $36.6 \%$. For statements as additional activity the percentage strongly agreed by $8.3 \%$, less agreed as much as $3.4 \%$. The statement of willingness has a very agreeable percentage of $6.7 \%$, less agree as much as $5 \%$.

Based on the results of this study farmers in Tinanggea and Palangga subdistricts have a percentage of entertainment motivation classified as a moderate category. Other motivations that encourage are social motivation and entertainment motivation [11, 12]. The motivation level of cattle farmers is mostly included in the high category of $45.9 \%$ and $28.6 \%$ of the moderate category and $25.5 \%$ of the low category. This means that respondents cultivate cattle because they have certain objectives related to their economy and social and hobbies or hobbies.

\section{Social Status Motivation}

The results of research in social status motivation fall into a very low category shows that farmers have a high social status motivation by choosing to disagree and disagree on statements about raising cows get respect in the community, raise cows can be respected, can improve family status, more recognized in the community and get awards. This can be seen in Fig 7 . 


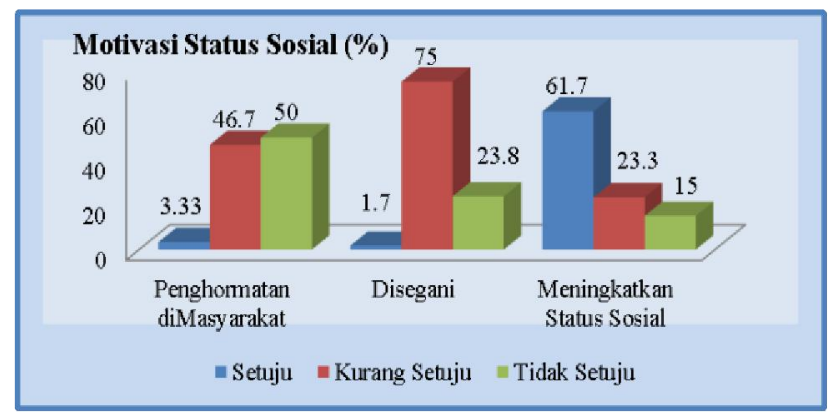

Fig. 7. Percentage of Social Status Motives of Raising Cows because they want to Earn Respect in the Community, in Segani and Improve Family Status

Fig 7. Showing the percentage of farmers in Tinanggea and Palangga subdistricts chose to disagree on the statement about raising cows to get respect from the community as much as $47 \%$, raising cows can be respected as much as $75 \%$ and can improve social status by $61.7 \%$. As for the percentage of attitudes strongly disagree and agree classified in the low category that is by raising cows get respect from the community agreed as much as $3.3 \%$, disagree as much as $45 \%$ and strongly disagree as much as $5 \%$. to raise cows can be respected to vote less agree as much as $75 \%$ and can improve the status of families choose to agree as much as $61.7 \%$.

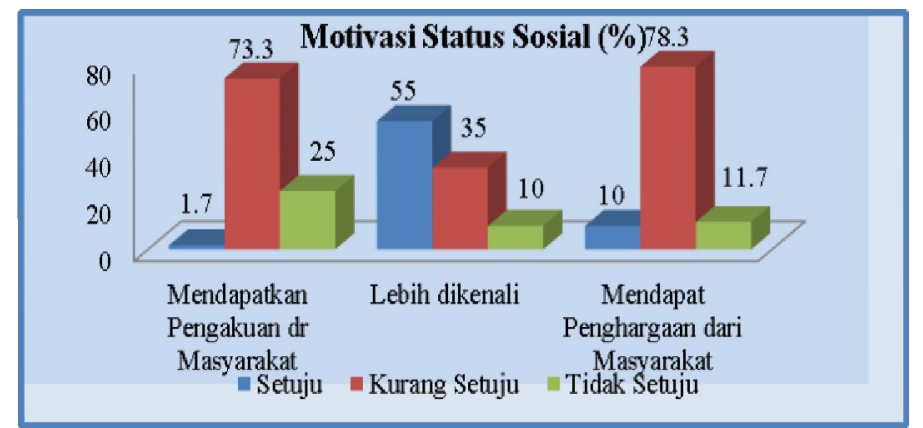

Fig. 8. Percentage of Social Status Motives Of Raising Cows Can Get Recognition from the Community, More Recognized and Awarded from the Community

Fig 8. Showing that the highest percentage of farmers in Tinanggea and Palangga subdistricts disagree on the statement about raising cows can get recognition from the community as much as $73 \%$ and cattle breeding gets an award from the community disagrees as much as $78.3 \%$. As for peresentase agree and strongly disagree belongs to the low category that is with the statement of raising cows can get recognition from the public agreed attitude as much as $1.7 \%$ and strongly disagree as much as $25 \%$. to raise cows got an award from the community attitude agree $55 \%$ and strongly disagree as much as $10 \%$ while to get an award from the public choose the attitude of agree as much as $10 \%$ and disagree as much as $11.7 \%$. 
Based on the results of this study farmers in Tinanggea and Palangga subdistricts prefer less agree on statements about raising cows can get respect in the community, can be respected, improve social status, get recognition from the community and get awards while for the statement more recognized farmers prefer agreed attitude. Having a job like raising cows, people value them more than people who don't have jobs. So they are interested in further advancing beef cattle farming to get a sense of appreciation from the community.

\section{CONCLUSION}

Based on the results of this study, it can be concluded that the system of maintenance of bali cattle in Tinanggea and Palangga subdistricts in general is still semi-intensive, The motivation of farmers to raise cattle in Tinanggea and Palangga subdistricts is Economic Motivation with a percentage of $68.8 \%$, environmental motivation $36 \%$, entertainment motivation $56 \%$ and social status motivation as much as $22 \%$, and the percentage level of motivation of cattle farmers in Tinanggea and Palangga subdistricts that most strongly encourage farmers to raise cows is economic motivation with a percentage score of as much as $68.8 \%$. It is expected that farmers in order to increase interest and achievement both in science and work experience, so that the efforts of cattle in the efforts of farmers can be developed and done well.

\section{ACKNOWLEDGMENTS}

Development of the livestock sector certainly provides opportunities in improving the economic sector of the community. We would like to express our gratitude to all the people of Tinanggea and Palangga subdistricts who contributed to the research.

\section{REFERENCES}

[1] A. Sasoeng, W. Tilaar, J. K. J. Kalangi, "Potential Development of Cattle Slaughter People In District Rainis Talaud Islands," Agri-Sosioekonomic, 16, 2020, pp. 291-300.

[2] S. R. Karimuna, S. Bananiek, S. Syafiuddin, W. A. Jumiati, "Potential of Livestock Commodity Development in Southeast Sulawesi," Journal of Tropical Animal Husbandry Science and Technology, 7, 2020, pp. 110-118.

[3] B. Brata, E. Soestrisno, B. D. Setiawan, H. P. Purba, "Population Identification, Business Management, and Marketing Patterns of Beef Cattle in The Farmer Resource Group of Kebawetan District, Kepahiang Regency," Indonesian Journal of Animal Science, 22, 2020, pp. 360-371.

[4] L. P. Aswara, M. Sarma, L. M. Baga, "Prospect of Sustainability Rural Agribusiness Business Development Programs In Purwakarta District," Journal Of Agribusiness Management, 8, 2020, pp. 154-164. 
[5] Harmoko, "Motivation Level of Farmers In Raising Cows In Sambas Subdistrict Sambas District," Journal of Social and Agricultural Economics, 10, 2017, pp. 1-10.

[6] J. Abidin, L. Malesi, H. A. Hadini, "Farmers' Motivation In Bali Cattle Business Development In West Muna Regency," Journal of Tropical Animal Husbandry Science and Technology, 5, 2018, pp. 17-23.

[7] E. Djuwendah, "Analysis of Economic Potentiality and Regional Inequality in Sumedang Regency,” Paspalum: Journal of Agricultural Sciences, 4,2017, pp. 12-28.

[8] H. Hildawati, R. M. Iswandi, S. Suriana, "Analysis of Base and Non Base Commodities of Livestock Sub-Sector in Kusambi Subdistrict, West Muna Regency," Scientific Journal of Agribusiness, 3, 2018, pp. 7-11.

[9] D. Ervina, A. Setiadi, T. Ekowati, “Analysis of Factors Influencing The Income of Dairy Cattle Business Group Farmers Rejeki Lumintu In Sumurrejo Subdistrict Gunungpati Semarang," SOCA, 13, 2019, pp. 184-200

[10] N. Hilmiati, "Cattle Farming System In Sumbawa Island: Opportunities And Barriers To Increase Productivity And Income of Farmers In Dry Land," SOCA, 13, 2019, pp. 142154.

[11] M. D. S. Randu, B. Hartono, "Sustainability of Economic Dimension, Infrastructure Technology, and Institutional Law for Sandelwood Horse Development Evaluation in Southwest Sumba Regency," Indonesian Animal Husbandry Sain Journal, 15, 2020, pp. 50-59.

[12] M. Haryo, A. Rifin, B. Sanim, "Factors Affecting Profitability on Animal Feed Companies in Indonesia," AE, 28, 2017, pp. 289-308. 